\title{
Digit ratio (2D:4D): A Potential Anatomical Biomarker for Predicting the risk of development of Polycystic Ovarian Syndrome
}

\author{
Dr.V.K.Pandit ${ }^{1}$, Dr.Mayura Setiya ${ }^{2}$, Dr.Sumitra Yadav ${ }^{3}$, Dr.Massarat Jehan ${ }^{4}$ \\ ${ }^{1}$ Associate Professor, ${ }^{2}$ Resident, Department Of Anatomy; \\ ${ }^{3}$ Professor, Department Of Obstetrics And Gynaecology; \\ ${ }^{4}$ (Corresponding Author) Assistant Professor, Department Of Anatomy; \\ Mahatma Gandhi Memorial Medical College \& M.Y. Hospital, Indore (M.P.) India.
}

\begin{abstract}
:
Introduction: Variable exposure to prenatal androgens may be responsible for the spectrum of endocrine and metabolic disturbances characteristic of Polycystic ovarian syndrome. Perinatal androgen level has been proved to play pivotal role in establishing finger lengths in foetus. It has been suggested that the $2 D: 4 D$ ratio is a negative correlate of prenatal testosterone and a positive correlate of prenatal estrogens. Once established in early neonatal life digit ratio assumed to be stable in later life.

Aims: To find out any possible association between digit ratio and developing PCOS

Methodology: 400 females (200 cases and 200 controls) of age group 18-40 were studied. The length of the index $(2 D)$ and ring finger (4D) were measured and $2 D: 4 D$ ratio were calculated and statistically analyzed.

Results: There was a significant difference $(p<0.0001)$ in $2 D: 4 D$ ratio between women with PCOS and the control group. Also $2 D: 4 D$ relationship is strong for right hand.

Conclusion: This anatomical expression can be used as a tool for early prediction of PCOS and hence substantiates the need for lifestyle modification to counteract this syndrome at its nascent stage
\end{abstract}

Keywords: Digit ratio, In-utero androgen exposure, Polycystic Ovarian Syndrome, 2D:4D.

\section{INTRODUCTION}

The digit ratio and its association to the phenotypic characteristics has been the focus of much research in recent years [1]. Digit ratio has been seen to show sexual dimorphism in relative and absolute lengths of index (2D) and ring finger (4D). The index to ring finger ratio has been reported to be smaller in males as compared to females [2-3]. The concept of digit ratio is popularized by an evolutionary psychologist Prof John Manning. He describes the digit ratio as a living fossil and a record of factors the foetus was exposed to at a critical time for the development of many other things [1].

The $2 \mathrm{D}: 4 \mathrm{D}$ ratio is thought to be determined by testosterone exposure during early intrauterine life. High concentration of foetal testosterone indicates a low 2D:4D which therefore indicates high prenatal testicular activity [3-6]. It has been suggested that the 2D:4D ratio is a negative correlate of prenatal testosterone and a positive correlate of prenatal estrogens [7]. The androgen receptors are present in the bones of hands and high androgen receptor activity has been associated with reduced 2D:4D ratio [1,8-9]. Also high androgen receptor activity, reflected by low numbers of CAG repeats [12-13]. The differentiation of the digits is under the control of Homeobox or Hox genes, which also controls the differentiation of testes and ovaries. This common control of the differentiation of the gonads and digits may therefore indirectly influence the prenatal production of testicular androgen and the development of the digits [1,5,11]. Once established in early neonatal life digit ratio assumed to be stable in later life [1,8]. Similarly in women conditions with elevated androgen concentration during foetal development can result in a masculine finger length pattern $[4,10]$.

Polycystic ovarian syndrome (PCOS) also called Hyperandrogenic Anovulation [14] or SteinLeventhal syndrome is one of the most common endocrine disorders among females. PCOS has a diverse range of causes. The precise aetiology of PCOS is unknown, but there is strong evidence that it is largely a genetic disease [15]. However variable exposure to prenatal androgens may be responsible for the spectrum of endocrine and metabolic disturbances characteristic of this syndrome [16-17]. PCOS produces symptoms in approximately $5-10 \%$ of women of reproductive age. It is thought to be one of the leading causes of female sub fertility [18-23]. The most common immediate symptoms are Anovulation, excess androgenic hormones and insulin resistance. Anovulation results in irregular menstruation, amenorrhea and ovulation related infertility [18-24]. 
In 2003 a consensus workshop sponsored by ESHRE (European Society of Human Reproduction and Embryology)/ASRM (American Society for Reproductive Medicine) in Rotterdam refined definition of PCOS [25]: namely the

1. Oligomenorrhea/or Anovulation

2. Hyperandrogenism (clinical or biochemical)

3. Polycystic ovaries, with the exclusion of other etiologies [24-25].

Prenatal testosterone exposure is known to decrease the 2D:4D ratio and as it is also associated with endocrine and metabolic disturbances in Polycystic ovarian syndrome. With this anatomical expression of sexhormonal predominance during intrauterine life, we tried to find out any possible relation of digit ratio with the developing PCOS in adulthood.

Since the 2D:4D ratio was first proposed as a marker for prenatal androgen action in 1998, many studies have been published that have either further tested the association between the digit ratio and prenatal androgens, or employed digit ratios as a marker to investigate the association between prenatal androgens and a variety of outcomes. So far only a few studies [13,16-17] have attempted to correlate PCOS and 2D:4D ratio. Numerous methods are used in the assessment of 2D:4D, however, some are not reliable enough and others are difficult to perform in large epidemiological studies [26]. According to Costas L et al. [26], the main source of variation was differences between subjects (real variation). His results suggest that reliability is influenced by participants' characteristics. Digit ratios determined directly with calipers are reliable when repeated measurements are averaged. Results with less number of sample population were prone to a number of drawbacks which may be major or minor errors which result in outlier values of $2 \mathrm{D}: 4 \mathrm{D}$ ratio. These drawbacks can be countered if large numbers of participants are recruited. Therefore we have taken 400 of population with 200 cases and 200 controls. This study focus on relation of digit ratio with PCOS about which little is known. Also to document bilateral variability in digit ratio if present and to determine the handedness which relates more with PCOS.

\section{MATERIALS AND METHODS}

The present study was conducted in Gynaecological OPD of MY hospital and M.G.M. Medical College, Indore (M.P.) India.

\subsection{Inclusion criteria:}

It included 200 women of age group 18-40 years which were diagnosed cases of PCOS either by a reproductive endocrinologist or gynaecologist on the basis of clinical history to determine menstrual irregularities or duration of infertility and Ultrasonography to detect the presence or absence of polycystic ovaries. These cases were compared with 200 regular cycling women of the same age group without PCOS.

\subsection{Exclusion criteria:}

Subjects below 18 years and above 40 years

- Subjects with injuries or deformities of digits

- Subjects with other aetiologies of androgen excess and anovulatory infertility such as hyperprolactinemia, thyroid dysfunction and congenital adrenal hyperplasia

- Subjects with pathological causes of oedema, hypertension and patients on drugs like diuretics, steroids which can affect vascular and extra vascular volume were also excluded.

\subsection{Methodology:}

The digit ratio is the ratio of the length of different digits or fingers typically measured from the midpoint of proximal crease of the digit to their tip[27,5]. Measurement of index (2D) to ring finger (4D) length ratio (2D:4D) were made on the ventral surface of the right and left hand from the most proximal basal crease of the digit to the tip of the finger in the mid line (Fig.1) and protruding finger nails were excluded. Volunteers were asked to remove any jewellery or rings that would interfere while obtaining finger lengths measurements. The procedure, aims and objectives of the study were explained to each subject. A written consent was taken from each subject. All the measurements were taken in a well-lighted room with overhead light.

Physical measurements were made on the ventral aspect by using Vernier Calipers without exerting pressure by a single experienced investigator to remove inter observer error. The left hand index finger were measured first followed by left ring, right index and then right ring finger. Measurements were taken twice for accuracy and to take out mean.The 2D:4D ratio for each hand were calculated by dividing the length of index finger by the length of ring finger. The $2 \mathrm{D}: 4 \mathrm{D}$ ratio $<1$ has been considered as a "male finger pattern" and $>1$ has been considered as a "female finger pattern" [3]. 


\subsection{Statistical evaluation:}

Data thus collected was compiled, tabulated and analysed statistically on word excel and SSP softwares. Descriptive statistics (Mean \pm SD) of the 2D:4D for the left and right hands were tabulated for all women with PCOS and female controls. Data obtained was analysed using student 't-test' and 'p-values' were calculated.

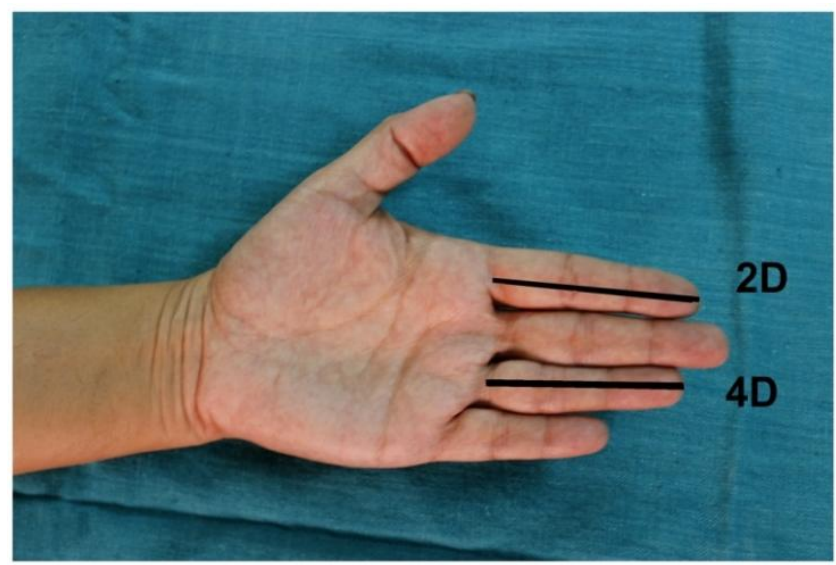

Fig. 1: Diagrammatic representation of digit ratio

\section{OBSERVATIONS AND RESULTS}

Clinical features of all women meeting the criteria for PCOS and female controls have been summarized in Table 1. Collectively, women with PCOS had higher incidence $(\mathrm{p}<0.0001)$ of acne, hirsutism and irregular menses. 70\% of women with PCOS were reported to demonstrate a delayed age of menarche when compared with a reference cohort of women without PCOS. In fact, some of control subjects (15\%) tend to demonstrate lower 2D:4D ratio and demonstrated delayed menarche.

Table 1: Distribution of Clinical symptoms in Cases and Controls

\begin{tabular}{|l|l|l|l|l|}
\hline \multirow{2}{*}{ Groups } & Cases & Controls \\
\cline { 2 - 5 } & $\mathbf{N = 2 0 0}$ & $\mathbf{\%}$ & $\mathbf{N = 2 0 0}$ & $\mathbf{\%}$ \\
\hline Acne & 128 & $64 \%$ & 44 & $22 \%$ \\
\hline Hirsutism & 124 & $62 \%$ & 16 & $08 \%$ \\
\hline Irregular Menses & 168 & $84 \%$ & 06 & $03 \%$ \\
\hline Delayed Menarche & 140 & $70 \%$ & 30 & $15 \%$ \\
\hline
\end{tabular}

Women with PCOS had higher ovarian volume measurements $(\mathrm{p}<0.0001)$ with the mean volume of ovary of right side with $11 \pm 02 \mathrm{cc}$ and that of left side with $11 \pm 2.2 \mathrm{cc}$ (as calculated through USG by the radiologists) compared to female controls which have bilaterally equal volumes of ovary within normal range of $7.94 \pm 2.34 \mathrm{cc}[28]$.

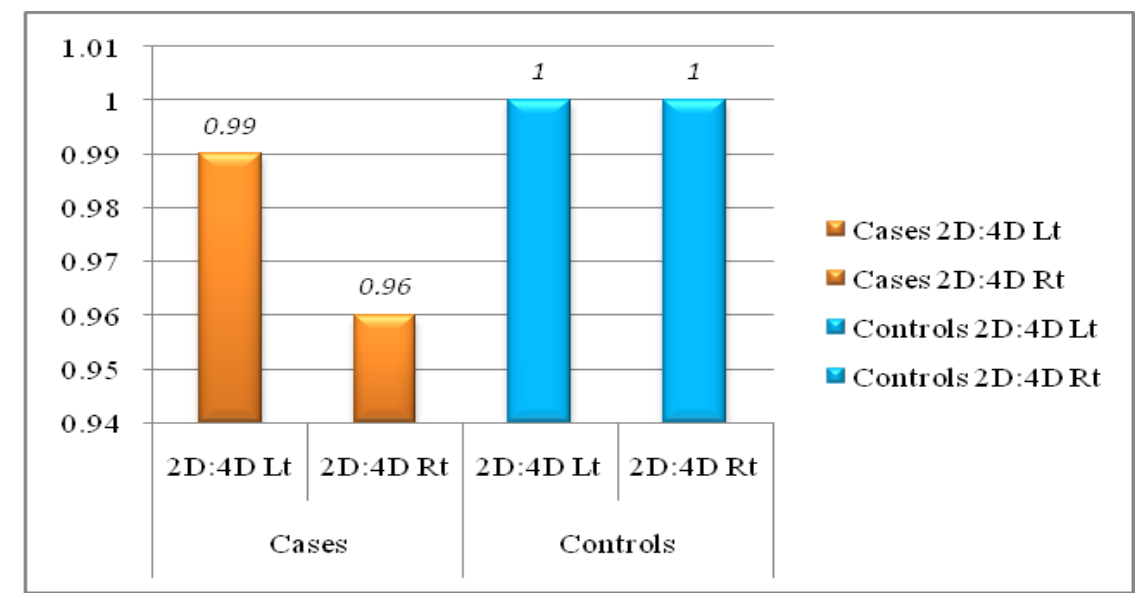

Graph 1: Comparison of digit ratio in Lt and Rt hand of cases and controls Table 2: Statistical calculations in Cases and Controls 
Digit Ratio (2D:4D): A Potential Anatomical Biomarker For Predicting The Risk Of ....

\begin{tabular}{|c|c|c|c|c|c|c|c|c|c|c|c|c|c|c|}
\hline \multicolumn{8}{|c|}{ Cases } & \multicolumn{7}{|c|}{ Controls } \\
\hline & $\begin{array}{l}\text { 2D: } \\
\text { 4D } \\
\text { Lt }\end{array}$ & $\begin{array}{c}\text { DD } \\
: 4 \\
\text { D } \\
\text { Rt }\end{array}$ & Age & $\begin{array}{c}\mathbf{W} \\
\mathbf{t} \\
(\mathbf{k} \\
\mathbf{g})\end{array}$ & $\begin{array}{c}\mathbf{H t} \\
(\mathbf{m})\end{array}$ & $\begin{array}{c}\text { B } \\
\text { MI }\end{array}$ & $\begin{array}{c}\text { Age at } \\
\text { menarc } \\
\text { he }\end{array}$ & $\begin{array}{l}\text { 2D: } \\
\text { 4D } \\
\text { Lt } \\
\text { Co }\end{array}$ & $\begin{array}{c}\text { 2D } \\
: 4 \\
\text { D } \\
\text { Rt } \\
\text { Co }\end{array}$ & Age & $\begin{array}{c}\mathrm{Wt} \\
(\mathrm{kg})\end{array}$ & $\begin{array}{l}\mathbf{H t} \\
(\mathbf{m})\end{array}$ & $\begin{array}{c}\text { B } \\
\text { MI }\end{array}$ & $\begin{array}{c}\text { Age at } \\
\text { menarc } \\
\text { he }\end{array}$ \\
\hline Min & 0.93 & $\begin{array}{c}0.9 \\
3\end{array}$ & 19 & 45 & 1.5 & 17 & 12 & 0.94 & $\begin{array}{c}0.9 \\
4\end{array}$ & 19 & 43 & 1.5 & 17 & 11 \\
\hline Max & 1.1 & 1.0 & 35 & 82 & 1.7 & 32 & 17 & 1.1 & 1.1 & 36 & 76 & 1.7 & 30 & 16 \\
\hline Mean & 0.99 & $\begin{array}{c}0.9 \\
6\end{array}$ & 24 & 66 & 1.6 & 26 & 14 & 1.0 & 1.0 & 24 & 60 & 1.6 & 24 & 13 \\
\hline SD & $\begin{array}{c}0.03 \\
8\end{array}$ & $\begin{array}{c}0.0 \\
21\end{array}$ & 3.7 & 8.7 & $\begin{array}{c}0.03 \\
6\end{array}$ & 3.2 & 1.1 & $\begin{array}{c}0.02 \\
8\end{array}$ & $\begin{array}{l}0.0 \\
28\end{array}$ & 3.9 & 7.0 & $\begin{array}{c}0.03 \\
1\end{array}$ & 2.7 & 1.2 \\
\hline $\begin{array}{c}\text { Std. } \\
\text { Error }\end{array}$ & $\begin{array}{c}0.00 \\
27\end{array}$ & $\begin{array}{c}0.0 \\
01 \\
5\end{array}$ & 0.26 & $\begin{array}{c}0.6 \\
2\end{array}$ & $\begin{array}{c}0.00 \\
26\end{array}$ & $\begin{array}{c}0.2 \\
2\end{array}$ & 0.077 & $\begin{array}{c}0.00 \\
20\end{array}$ & $\begin{array}{c}0.0 \\
02 \\
0\end{array}$ & 0.27 & 0.49 & $\begin{array}{c}0.00 \\
22\end{array}$ & $\begin{array}{c}0.1 \\
9\end{array}$ & 0.088 \\
\hline $\mathrm{CV} \%$ & 3.81 & $\begin{array}{c}2.1 \\
9\end{array}$ & $\begin{array}{c}15.6 \\
0\end{array}$ & $\begin{array}{l}13 . \\
29\end{array}$ & 2.29 & $\begin{array}{l}12 . \\
28\end{array}$ & 7.69 & 2.80 & $\begin{array}{c}2.7 \\
4\end{array}$ & $\begin{array}{c}15.8 \\
9\end{array}$ & $\begin{array}{c}11.5 \\
7\end{array}$ & 1.98 & $\begin{array}{l}11 . \\
29\end{array}$ & 9.89 \\
\hline
\end{tabular}

Min= Minimum $\quad$ Max= Maximum $\quad \mathrm{SD}=$ Standard Deviation

$\mathrm{CV}=$ Coefficient of variation

Statistical calculations of cases and controls have been summarized in Table 2 and 3. Women with PCOS had low 2D:4D ratio (Graph 1), increased weight, high BMI and delayed age of menarche which were highly significant $(\mathrm{p}<0.0001)$. The differences in mean 2D:4D ratio between the PCOS and the control groups (Table 3) was greater on the right hand $(-0.051 \pm 0.0025)$ with a t value of 21 , compared with that of the left ($0.029 \pm 0.0033)$ with $t$ value of 8.6 which means the $2 \mathrm{D}: 4 \mathrm{D}$ relationship is strong for right hand.

Table 3: Unpaired t test and F test Results

\begin{tabular}{|c|c|c|c|c|c|c|c|c|c|}
\hline \multirow{2}{*}{$\begin{array}{l}\text { Unpaired } t \\
\text { test }\end{array}$} & Cases & Control & \multicolumn{7}{|c|}{ Cases vs Controls } \\
\hline & $\begin{array}{c}\text { 2D:4D } \\
\text { Lt vs Rt }\end{array}$ & $\begin{array}{c}\text { 2D:4D } \\
\mathrm{Lt} \text { vs Rt }\end{array}$ & $\begin{array}{c}\text { 2D:4D } \\
\mathrm{Lt}\end{array}$ & $\begin{array}{c}\text { 2D:4D } \\
\text { Rt }\end{array}$ & Age & Wt (kg) & $\mathrm{Ht}(\mathrm{m})$ & BMI & $\begin{array}{l}\text { Age at } \\
\text { menarch } \\
\mathrm{e}\end{array}$ \\
\hline $\mathrm{p}$ value & $\begin{array}{c}\mathrm{P}<0.000 \\
1\end{array}$ & 0.9111 & $\begin{array}{c}\mathrm{P}<0.000 \\
1\end{array}$ & $\begin{array}{c}\mathrm{P}<0.000 \\
1\end{array}$ & $\begin{array}{c}0.03 \\
48\end{array}$ & $\begin{array}{c}\mathrm{P}<0.000 \\
1\end{array}$ & 0.2844 & $\begin{array}{c}\mathrm{P}<0.00 \\
01\end{array}$ & $\begin{array}{c}\mathrm{P}<0.000 \\
1\end{array}$ \\
\hline $\begin{array}{c}\mathrm{p} \text { value } \\
\text { summary }\end{array}$ & $* * *$ & ns & $* * *$ & $* * *$ & * & $* * *$ & ns & $* * *$ & $* * *$ \\
\hline $\mathrm{t}$ value & $t=7.3$ & $\mathrm{t}=0.11$ & $t=8.6$ & $t=21$ & $\begin{array}{c}\mathrm{t}=2 . \\
1\end{array}$ & $\mathrm{t}=6.9$ & $\mathrm{t}=1.1$ & $\mathrm{t}=6.8$ & $t=13$ \\
\hline $\begin{array}{c}\text { Difference } \\
\text { between } \\
\text { means }\end{array}$ & $\begin{array}{c}0.022 \pm \\
0.0030\end{array}$ & $\begin{array}{l}-0.00031 \\
\pm 0.0028\end{array}$ & $\begin{array}{c}-0.029 \pm \\
0.0033\end{array}$ & $\begin{array}{c}-0.051 \pm \\
0.0025\end{array}$ & $\begin{array}{c}- \\
0.80 \\
\pm \\
0.38\end{array}$ & $\begin{array}{c}5.4 \pm \\
0.79\end{array}$ & $\begin{array}{c}0.0036 \\
\pm \\
0.0034\end{array}$ & $\begin{array}{c}2.0 \pm \\
0.29\end{array}$ & $\begin{array}{l}1.5 \pm \\
0.12\end{array}$ \\
\hline $\begin{array}{c}95 \% \\
\text { confidence } \\
\text { interval }\end{array}$ & $\begin{array}{c}0.016 \text { to } \\
0.028\end{array}$ & $\begin{array}{c}-0.0058 \\
\text { to } \\
0.0052\end{array}$ & $\begin{array}{c}-0.035 \text { to } \\
-0.022\end{array}$ & $\begin{array}{c}-0.056 \text { to } \\
-0.046\end{array}$ & $\begin{array}{c}-1.5 \\
\text { to }- \\
0.06 \\
0\end{array}$ & $\begin{array}{c}3.9 \text { to } \\
7.0\end{array}$ & $\begin{array}{c}-0.0030 \\
\text { to } \\
0.010\end{array}$ & $\begin{array}{c}1.4 \text { to } \\
2.6\end{array}$ & $\begin{array}{c}1.2 \text { to } \\
1.7\end{array}$ \\
\hline R squared & 0.12 & $\begin{array}{c}0.00003 \\
1 \\
\end{array}$ & 0.16 & 0.52 & $\begin{array}{c}0.01 \\
1 \\
\end{array}$ & 0.11 & 0.0029 & 0.10 & 0.28 \\
\hline \multicolumn{10}{|c|}{ F test to compare variances: } \\
\hline F value & 3.2 & 1.0 & 1.7 & 1.7 & 1.1 & 1.6 & 1.3 & 1.4 & 1.3 \\
\hline $\mathrm{p}$ value & $\begin{array}{c}\mathrm{P}<0.000 \\
1\end{array}$ & 0.3803 & $\begin{array}{c}\mathrm{P}<0.000 \\
1\end{array}$ & $\begin{array}{c}\mathrm{P}<0.000 \\
1\end{array}$ & $\begin{array}{c}0.23 \\
12\end{array}$ & 0.0008 & 0.0202 & 0.0103 & 0.0232 \\
\hline $\begin{array}{c}\mathrm{p} \text { value } \\
\text { summary }\end{array}$ & **** & ns & *** & $* * *$ & ns & **** & $*$ & $*$ & $*$ \\
\hline
\end{tabular}

There was a non significant negative relationship between the right hand finger length ratio and BMI (i.e., as the BMI increased, the finger length ratio decreased; Pearson correlation coefficient $=-0.064 ; \mathrm{P}=.37$ ). But in left hand finger length ratio there was a weak significant positive relationship (Pearson $\mathrm{r}=0.14 ; \mathrm{P}=.042$ ).

\section{DISCUSSION}

The prenatal androgens might contribute to development of PCOS has been retrospectively investigated by Cattrall et al., 2005 [13] using a putative anatomical marker of in utero androgen exposure. He found a small, yet significant, difference in the right hand 2D:4D of women with PCOS compared to healthy female controls (98.3\% of that in the controls) providing support for prenatal androgens in the etiology of PCOS which is consistent with our study. The groups were similar with respect to age and height but differed in BMI. The average age of the PCOS group was $28.7 \pm 5.0$ years and $28.7 \pm 5.6$ years in the control group. The average 
height of the PCOS group was $163.8 \pm 8.2 \mathrm{~cm}$ and $164.4 \pm 6.1 \mathrm{~cm}$ in the control group. He found that $59 \%$ of the PCOS women were obese with a BMI more than $30 \mathrm{~kg} / \mathrm{m}^{2}$, compared to $7 \%$ in the control group. The mean BMI of the PCOS group was $29.2 \pm 6.5 \mathrm{~kg} / \mathrm{m}^{2}$. In the control group the mean BMI was $23.5 \pm 4.4 \mathrm{~kg} / \mathrm{m}^{2}$. Similarly in my study groups were similar with respect to age and height but differed in weight and BMI. The average age of the PCOS group was $24.35 \pm 5.0$ years and $24.35 \pm 5.6$ years in the control group. The average height of the PCOS group was $159 \pm 3.8 \mathrm{~cm}$ and $159 \pm 3.0 \mathrm{~cm}$ in the control group. The mean BMI of the PCOS group was $25.79 \pm 3.1 \mathrm{~kg} / \mathrm{m}^{2}$ and that of control group was $23.7 \pm 2.5 \mathrm{~kg} / \mathrm{m}^{2}$. Cattrall et al. used NIH criteria to define PCOS which did not included ultrasonic evidence of polycystic ovaries and conducted his studies on 70 women aged between 18-40 years with PCOS and compared it with 70 women of same age group without PCOS. Although we used Rotterdam criteria to define PCOS which also included USG as a measure to diagnose women with PCOS, then also our results are consistent with his study.

Lujan ME et al. [16], concluded that women with PCOS do not demonstrate finger length patterns that are consistent with increased prenatal androgen exposure and precluded that digit ratios measured by Vernier callipers do not serve as anatomical evidence of prenatal androgen exposure in PCOS which contradict our and Cattrall results. In her study collectively, women with PCOS tended to be slightly older $(P=0.068)$, of greater body mass index (BMI; $P<0.001)$, and had larger waist circumferences $(P<0.001)$ and reported longer menstrual cycles $(P<0.001)$ compared with controls. Mean 2D:4D in the left $(0.991 \pm 0.030$ versus $0.981 \pm$ 0.038 , respectively; $P=0.093)$ and right $(0.983 \pm 0.031$ versus $0.981 \pm 0.031$, respectively; $P=0.634)$ hands of women with PCOS did not differ from that of controls.

In another study by Lujan ME et al. [17] she showed that women with four clinical phenotypes of PCOS do not demonstrate anatomical evidence of elevated prenatal androgen exposure as judged by a lower 2D:4D ratio. This time finger lengths were not measured using Vernier callipers but their hands were digitally scanned which was considered as a more reliable method by her.

There are several reasons why our and Cattrall et al. results differ from that of Lujan $e t$ al. One of it may be because she used different criteria to define PCOS by categorizing it into four clinical phenotypes. Another reason may be due to the fact that she determined digit ratio in 98 PCOS women and in 51 controls which differ from our study group which included large population groups (400) with equal number of cases and control (200 each). Although we both used the same Rotterdam criteria for diagnosing PCOS but since she conducted her study in different region with different race, genetic constitution and environmental factors which may also have some affect on the results to an extent. There may also be significant hormonal and morphological differences among the control subjects investigated by both studies.

The digit ratio has also been associated by many authors with several characteristics such as congenital adrenal hyperplasia [10,29], developmental psychopathology, Autism and Aspergers syndrome [30], Down's syndrome [1], Physical aggression [31], Sperm counts [7,32], family size [33], age at myocardial infarction [34], good visualspatial ability [35], late menarche and time to pregnancy [36], eating disorders [37], fetal growth and birth weight [38-40], alcohol dependency [41], breast cancer [42-43], and prostate cancer risk [44-45].

Women with congenital adrenal hyperplasia who are genetically programmed to produce in utero androgens have masculine finger length patterns [10], commonly exhibit a PCOS-like syndrome with hypersecretion of luteinizing hormone and ovarian hyperandrogenism, suggesting prenatal testosterone excess as a possible PCOS etiology [46].

We found that the differences in the second to fourth finger length ratios were greater on the right hand compared with the left. Similarly, studies of women with congenital adrenal hyperplasia and homosexual women have also reported lower finger length ratios on the right hand [10,47]. It may be because that the right hand is more sensitive to fetal androgens than the left [6] or it may represent more rapid cell division on the right side of the body during embryological development [48]. In one study, no difference could be found in the left hand finger length ratio in women with congenital adrenal hyperplasia [4]. A number of other studies have also shown the right 2D:4D to be a stronger predictor of index traits than the left; for e.g. testosterone and sperm counts [7], fetal growth [38], athletic ability [35] and MI [34]. These traits could help in the identification of fetal origins of adult diseases, as they reflect the endocrine signaling during the prenatal period [26].

\section{CONCLUSION}

We concluded that women with PCOS can have masculinized finger length patterns with low 2D:4D consistent with increased prenatal androgen exposure. There was a subtle but significant difference $(p<0.0001)$ between women with PCOS and the control group and therefore our findings also suggest a role for in utero androgens in the development of PCOS. We also found that the differences in the 2D:4D ratios were greater on the right hand compared with the left. This anatomical expression can be used as a tool for early prediction of PCOS and hence substantiates the need for lifestyle modification to counteract this syndrome at its nascent stage. 


\section{REFERENCES}

[1]. Viveka S, Sudha MJ, Udyavar A, Bidarkotimath S. Digit ratio and Down syndrome correlation with perinatal androgen levels. International Journal of Comprehensive Medical Physiology and Research. 2014; 1(1):25-33.

[2]. Geetha KN, Patel SC, Chavan LN, Shinde C. Hand digit ratio (2D:4D) and sexual dimorphism in different age groups. Journal of Clinical Research Letters. 2012; 3(1):16-18.

[3]. Jain M, Dhall U, Pandey S, Jain S. Second to fourth digit ratio (2D:4D) in north-west Indians: Sexual Dimorphism. J. Anatomical Society India. 2012; 61(2):242-45.

[4]. Buck J, Williams R, Hughes I, Acerini C. In-utero androgen exposure and 2nd to 4th digit length ratio, comparisons between healthy controls and females with classical congenital adrenal hyperplasia. Hum Reprod. 2003; 18: 976-79.

[5]. Lutchmaya S, Baron-Cohen S, Raggatt P, Knickmeyer R, Manning JT. 2nd to 4th digit ratios, fetal testosterone and estradiol. Early Hum Dev. 2004; 77:23-28.

[6]. Roney JR, Whitham JC, Leoni M, Bellem A, Wielebnowski N, Maestripieri D. Relative digit lengths and testosterone levels in Guinea baboons. Horm Behav. 2004; 45: 285-90.

[7]. Manning JT, Scutt D, Wilson J, Lewis-Jones DI. The ratio of 2nd to 4th digit length: a predictor of sperm numbers and concentrations of testosterone, luteinizing hormone and oestrogen. Hum Reprod. 1998; 13:3000-04.

[8]. Manning JT. Digit ratio: A pointer to Fertility. Behavior and Health. 2002; 24-40.

[9]. Manning JT, Bundred PE, Newton DJ, Flanagan BF. The second to fourth digit ratio and variation in the androgen receptor gene. Evol Hum Behav. 2003; 24:399-405.

[10]. Brown WM, Hines M, Fane BA, Breedlove SM. Masculinised finger length patterns in human males and females with congenital adrenal hyperplasia. Hormones and Behavior. 2002; 42 (4): 380-6.

[11]. Mortlock DP, Innis JW. Mutation of Hox A13 in hand-foot- genital syndrome. Nature Genet. 1997; 15: 179-180.

[12]. Manning JT, Bundred PE, Flanagan BF. The ratio of 2nd to 4th digit length (a proxy for transactivation activity of the androgen receptor gene?) . Med Hypotheses. 2002; 59: 334-36.

[13]. Cattrall FR, Vollenhoven BJ, Weston GC. Anatomical evidence for in utero androgen exposure in women with polycystic ovary syndrome. Fertil Steril. 2005; 84:1689-1692.

[14]. Kollmann M, Martins WP, Raine-Fenning N. Terms and thresholds for the ultrasound evaluation of the ovaries in women with hyperandrogenic Anovulation. Hum. Reprod. Update 2014; 20(3): 463-64.

[15]. Diamanti-Kandarakis E, Kandarakis H, Legro RS. The role of genes and environment in the etiology of PCOS. Endocrine. 2006; 30(1):19-26.

[16]. Lujan ME, Bloski GT, Chizen DR, Lehotay DC, Pierson RA. Digit ratios do not serve as anatomical evidence of prenatal androgen exposure in clinical phenotypes of polycystic ovary syndrome. Human Reprod. 2010; 25(1):204-211.

[17]. Lujan et al. Digit ratios by computer-assisted analysis confirm lack of anatomical evidence of prenatal androgen exposure in clinical phenotypes of polycystic ovary syndrome. Reproductive Biology and Endocrinology. 2010; 8:156.

[18]. Dumesic DA, Abbott DH, Eisner JR, Goy RW. Prenatal exposure of female rhesus monkeys to testosterone propionate increases serum luteinizing hormone levels in adulthood. Fertil Steril. 1997; 67: 155-163.

[19]. Abbott DH, Dumesic DA, Franks S. Developmental origin of polycystic ovary syndrome —a hypothesis. J Endocrinol. 2002; 174: $1-5$.

[20]. Norman RJ. Hyperandrogenaemia and the ovary. Mol Cell Endocrinol. 2002; 191: 113-119.

[21]. Azziz R, Woods KS, Reyna R, Key TJ, Knochenhauer ES, Yildiz BO. The Prevalence and Features of the Polycystic Ovary Syndrome in an Unselected Population. Journal of Clinical Endocrinology \& Metabolism. 2004; 89(6): 2745-9.

[22]. Boomsma CM, Fauser BC, Macklon NS. Pregnancy complications in women with polycystic ovary syndrome. Semin. Reprod. Med. 2008; 26(1): 72-84.

[23]. Goldenberg N, Glueck C. Medical therapy in women with polycystic ovary syndrome before and during pregnancy and lactation. Minerva Ginecol .2008; 60(1): 63-75.

[24]. Pratap K, Narendra M. Polycystic ovarian Syndrome . In: Jeffcoates (ed) Principles of Gynaecology. $7^{\text {th }}$ ed. Jaypee; 2008 p.384393.

[25]. The Rotterdam ESHRE/ASRM-sponsored PCOS consensus workshop group. Revised 2003 consensus on diagnostic criteria and long-term health risks related to polycystic ovary syndrome. Fertil Steril. 2004; 81: 19-25.

[26]. Costas L et al. Reliability of 2D:4D measurements using a direct method suitable for clinical settings. Personality and Individual Differences. 2013; 55: 339-342.

[27]. Mayhew TM, Gillam L, McDonald R, Ebling FJP. Human 2D (index) and 4D (ring) digit lengths: their variation and relationships during the menstrual Cycle. Journal of Anatomy. 2007; 211 (5): 630-638.

[28]. Kennedy A. Polycystic ovarian syndrome. In: Ahuja AT (ed). Diagnostic imaging Ultrasound. $1^{\text {st }}$ ed. Canada, Amirsys/Elsevier; 2007 p.94-95.

[29]. Okten A, Kalyonku M, Yaris N. The ratio of second-and fourth-digit lengths and congenital adrenal hyperplasia due to 21hydroxylase deficiency. Early Hum Dev. 2002; 70:47-54.

[30]. Manning JT, Baron Cohen S, Wheelwright S, Sanders G. The 2nd to 4th digit ratio and autism. Dev Med Child Neurology. 2001; 43: $160-164$.

[31]. Benderlioglu Z, NelsonRJ. Digit length ratios predict reactive aggression in women, but not in men. Hormones and Behavior. 2004; 46:558-564.

[32]. Wood S, Vang E, Manning J, Walton J, Troup S, Kingsland C, et al.. The ratio of second to fourth digit length in azoospermic males undergoing surgical sperm retrieval: predictive value for sperm retrieval and on subsequent fertilization and pregnancy rates in IVF/ICSI cycles. Journal of Andrology. 2003; 24(6):871-877.

[33]. Manning JT, Barley L, Lewis-Jones I, et al. The 2nd to 4th digit ratio, sexual dimorphism, population differences and reproductive success: evidence for sexually antagonistic genes. Evol Hum Behav. 2000; 21:163-83.

[34]. Manning JT, Bundred PE. The 2nd to 4th digit ratio and age at first myocardial infarction in men: evidence for a link with prenatal testosterone? Br J Cardiol. 8:720-23.

[35]. Manning JT, Taylor RP. Second to fourth digit ratio and male ability in sport: implications for sexual selection in humans. Evol Hum Behav. 2001; 22:61-69.

[36]. Manning JT, Fink B. Is low digit ratio linked with late menarche? Evidence from the BBC internet study. American Journal of Human Biology. 2011; 23(4):527-33.

[37]. Quinton SJ, Smith AR, Joiner T. The 2nd to 4th digit ratio (2D:4D) and eating disorder diagnosis in women. Personality and Individual Differences. 2011; 51(4):402-05. http://dx.doi.org/10.1016/j.paid.2010.07.024. 
[38]. Ronalds G, Phillips DIW, Godfrey KM, Manning JT. The ratio of second to fourth digit lengths: a marker of impaired fetal growth? Early Hum. Dev. 2002; 68:21-26.

[39]. McIntyre MH, Cohn BA, Ellison PT. Sex dimorphism in digital formulae of children. Am J Phys Anthropolm. 2006; 129:143-50

[40]. Danborno B, Adebisi SS, Adelaiye AB, Ojo SA. Relationship between Digit Ratio (2D:4D) and Birth Weight in Nigerians. Anthropologist. 2010; 12(2): 127-30.

[41]. Kornhuber J, Erhard G, Lenz B, Kraus T, Sperling W, Bayerlein K, et al. Low digit ratio 2D:4D in alcohol dependent patients. PloS One. 2011; 6(4): e19332. http://dx.doi.org/10.1371/journal.pone.0019332.

[42]. Muller DC, Baglietto L, Manning JT, McLean C, Hopper JL, English DR, et al. Second to fourth digit ratio (2D: 4D), breast cancer risk factors, and breast cancer risk: a prospective cohort study. British Journal of Cancer. 2012; 107(9):1631-36.

[43]. Manning JT, Leinster S. The ratio of 2 nd to 4 th digit length and age at presentation of breast cancer: a link with prenatal oestrogen? Breast. 2001; 10:355-57.

[44]. Rahman AA, Lophatananon A, Stewart-Brown S, Harriss D, Anderson J, Parker T, et al. Hand pattern indicates prostate cancer risk. British Journal of Cancer. 2011; 104(1):175-77.

[45]. Muller DC, Giles GG, Manning JT, Hopper JL, English DR, Severi G. Second to fourth digit ratio (2D:4D) and prostate cancer risk in the Melbourne Collaborative Cohort Study. British Journal of Cancer. 2011; 105(3):438-40.

[46]. Barnes R, Rosenfield R, Ehrmann D, Cara J, Cuttler L, Levitsky L, et al. Ovarian hyperandrogenism as a result of congenital adrenal virilizing disorders (evidence for perinatal masculinization of neuroendocrine function in women). J Clin Endocrinology and Metabolism. 1994; 79: 1328-33.

[47]. Williams TJ, Pepitone ME, Scott E, Christensen BM, Cooke AD. et al. Finger-length ratios and sexual orientation. Nature. 2000; 404: 455.

[48]. Kimura D, Carson MW. Dermatoglyphic asymmetry (relation to sex handedness and cognitive pattern). Person Individ Diff. 1995; 19: 471-478. 